ORIGINAL ARTICLE / ARTIGO ORIGINAL

\title{
Characteristics of hormone use by travestis and transgender women of the Brazilian Federal District ${ }^{*}$
}

\section{Características do uso de hormônios por travestis e mulheres transexuais do Distrito Federal brasileiro}

\author{
Alícia Krüger' (D, Sandro Sperandei", Ximena Pamela Claudia Diaz Bermudez', \\ Edgar Merchán-Hamann'
}

\begin{abstract}
Introduction: Travestis and transgender women resort to the use of hormones for body modification. Due to restrictions in the access to health services, self-medication is frequent. The aim of this study was to describe the self-reported prevalence of hormones used by travestis and transgender women in the Federal District. Method: This is a cross-sectional study with Respondent Driven Sampling (RDS) and Knowledge, Attitudes and Practices questionnaire (KAP) along with travestis and transgender women over 18 years in the FD. Prevalence was calculated using the RDS-II estimator. Logistic models were used to investigate the associated factors. A total of 201 volunteers participated. Results: There was a young sample (median age of 24 years). The overall prevalence of continuous use of hormones was $64.5 \%$. The most used formulation was the combination of estrogen and progesterone $(86.2 \%)$ by injectable $(75.1 \%)$ and oral $(66 \%)$ administration. Most participants (84\%) got the hormones without a prescription. Guidance on the use of these hormones came from their peers in $41 \%$ of the cases. We observed that the continuous use of hormones is associated with race, income and age, as well as the search for guidance of healthcare professionals, which is also associated with schooling. Discussion: The reality of the process of hormone use by these people in the quest for femininity is reflected in high rates of self-medication. Conclusion: This study contributes to the visibility of the need to improve the access conditions of these people to health services.
\end{abstract}

Keywords: Transgender people. Hormones. Body. Health services accessibility.

This study was part of a master's thesis on Collective Health by the first author, entitled Aviões do Cerrado: uso de hormônios por travestis e mulheres transexuais do Distrito Federal brasileiro, defended in December 2018 in the Post-Graduate Program in Collective Health at the School of Health Sciences at the University of Brasilia.

IPost-Graduate Program in Collective Health, School of Health Sciences, University of Brasília, Brasília (DF), Brazil.

"Institute of Communication and Scientific Information and Technology in Health, Oswaldo Cruz Foundation, Rio de Janeiro (RJ), Brazil. Corresponding author: Alícia Krüger. School of Health Sciences. University of Brasília. Asa Norte, CEP: 70910-900 - Brasília, DF, Brazil. E-mail: alybk1@hotmail.com

Conflict of interests: nothing to declare - Financial support: Department of Chronic Conditions Diseases and Sexually Transmitted Infections, Secretariat of Health Surveillance, Ministry of Health of Brazil. 
RESUMO: Introdução: Travestis e mulheres transexuais recorrem ao uso de hormônios para modificação corporal. Devido a restrições de acesso a serviços de saúde, a automedicação é frequente. Objetivou-se descrever a prevalência autorrelatada do uso de hormônios por travestis e mulheres transexuais do Distrito Federal e fatores associados. Método: Trata-se de estudo transversal, com amostragem por Respondent Driven Sampling (RDS) e questionário do tipo Conhecimentos, Atitudes e Práticas (CAP) aplicado a 201 travestis e mulheres transexuais maiores de 18 anos, vinculadas ao Distrito Federal. As prevalências foram calculadas pelo estimador RDS-II. Foram utilizados modelos logísticos na investigação dos fatores associados. Resultados: Obteve-se uma amostra jovem (mediana de idade de 24 anos). A prevalência geral de uso contínuo de hormônios foi de $64,5 \%$. A formulação mais utilizada foi a que combina estrogênio e progesterona $(86,2 \%)$, nas vias injetável $(75,1 \%)$ e oral $(66 \%)$. A maioria das participantes (84\%) consegue os hormônios sem receituário médico. As orientações sobre o uso desses hormônios vêm de seus pares, em $41 \%$ dos casos. Observou-se que o uso contínuo de hormônios está associado à raça, renda e idade, assim como a busca por orientação de profissionais de saúde, que também está relacionada à escolaridade. Discussão: Nota-se que o processo de hormonização destas pessoas na busca pela feminilidade se reflete em altas taxas de automedicação. Conclusão: Este estudo contribui na visibilidade da necessidade de melhorar as condições de acesso destas pessoas a serviços de saúde.

Palavras-chave: Pessoas transgênero. Hormônios. Corpo. Acesso aos serviços de saúde.

\section{INTRODUCTION}

Transgender people can be understood as those whose gender identity does not conform to the norms imposed by society regarding the gender designated at birth, based on the genitalia ${ }^{1}$. The transgender category is quite broad and involves travestis, transgender men and women as well as non-binary persons ${ }^{2}$. This study will focus on travestis and transgender women, who are designated as males at birth but have developed a female gender identity ${ }^{2}$. Much more than differences marked by genital surgeries or the ingestion of hormones, these two identities are distinguished by political and/or subjective connotation ${ }^{3}$. These categories were mixed with questions related only to sexual orientation-an interpretation that limits their identity nature. Transgender people demand, above all, social recognition and respect for their identity ${ }^{4}$.

Many travestis and transgender women resort to biomedical technologies to suppress traits considered masculine, in order for the so-called female characteristics to manifest themselves in their bodies ${ }^{5,6}$. The attempt to affirm these female stereotypes occurs by their own desire, search for comfort and satisfaction with their own image, or by framing female models as a resource to escape the prejudice associated with the body/identity device?

For Butler, the normalization of trans women's bodies places them as abject bodies, that is, foreign bodies causing repulsion and exclusion, which turns them into "precarious lives"s. One of the medical technologies used by travestis and transgender women for body feminization is the use of hormones. 
In Brazil, hormonalization should be prescribed by a doctor ${ }^{8}$. However, most transgender people self-medicate and do not resort to health services to perform their hormonalization. This is due to the scarcity of services and medical professionals who have mastered the specificities of the transgender matter and are able to prescribe drugs safely for these users ${ }^{9}$. Another obstacle is the prejudice rooted in the culture of health professionals who disrespect and delegitimize transgender identities, in addition to persisting pathological perspectives concerning these people ${ }^{9}$. On the other hand, it is known that self-medication is a practice conducted among transgender women and travestis; therefore, when they access such services, they have already been using hormones by indication of people in their respective networks or by information obtained on the Internet ${ }^{10,11}$.

Even in the face of so many barriers, those who can access health services can opt for private consultations or for free care in the Unified Health System (SUS), through Processo Transexualizador (Transexualizing Process), instituted in Brazil in 2008 ${ }^{12,13}$. This norm guarantees travestis and transgenders multidisciplinary follow-up as well as surgical and hormonal procedures ${ }^{13}$.

For travestis and transgender women, homornalization consists in the administration of estrogen by oral or injectable route and antiandrogens that block the excessive action of testosterone $\mathrm{e}^{14,15}$. This process should be individualized, based on personal goals, risk/benefit ratio of medications and health conditions, and take into account socioeconomic issues ${ }^{16}$.

In view of the above, this article discusses the use of hormones by travestis and transgender women of the Brazilian Federal District and some associated factors.

\section{METHOD}

This is a cross-sectional epidemiological study based on the Respondent Driven Sampling (RDS) methodology, based on a Knowledge, Attitudes and Practices questionnaire ${ }^{17}$. This cut is derived from data from the Federal District collected in the "Estudo de abrangência nacional de comportamentos, atitudes, práticas e prevalência de HIV, Sífilis e Hepatites B e C entre Travestis” - Pesquisa Diversidade e Valorização da Saúde (Divas), held in 12 Brazilian capitals. This article focuses on the use of hormones for the body modification of travestis and transgender women.

As inclusion criteria, participants should: be 18 years of age or more; have been designated as males at birth, identified as belonging to the female gender; and have some connection with the Federal District (work, live, study and/or spend most of the time); and never having participated in this research, carrying a valid and unpublished invitation delivered by another already interviewed participant ${ }^{17}$. According to the RDS methodology, each participant could invite only 3 travestis/transgender women. All were reimbursed for the costs of travel and stay at the data collection site. A total of 201 people belonging to networks generated from ten "seeds" participated. 
This study was carried out between May and September 2017 at the No. 1 Health Center of Brasília, Hospital-Dia, including conventional socio-demographic variables, gender identity and transition age. In this article we used the variables that detail the characteristics of hormone use.

Prevalences were calculated by means of the RDS-II ${ }^{18}$ estimator, with $95 \%$ confidence intervals. Initially, the size of each individual's contact network was established by answering the question: "From the people you know by name/ surname and who also know you by name/surname, how many you met or spoke in person, by phone or Facebook/WhatsApp in the last 30 days?". Based on this value, we assigned a sample weight for each individual equal to the reverse of the network size. Thus, the likelihood of being included in the search was adjusted due to network profile similarities. All analyses were performed in R, version 3.4. $4^{18}$ using the $\mathrm{RDS}^{19}$ software package.

Logistic models were created to investigate the association between demographic variables related to the questions "Do you make continuous use of hormones?" and "Have you received advice from a health care professional about the use of hormones?". The women who answered yes to the second question had been guided by health professionals in general or endocrinologists, with them being grouped under the category Health Professionals and the remaining being grouped under Others. In each model, the following variables were evaluated: "Have you done sex work in the last 30 days?"; age group; race/color; schooling; and income. When necessary and adequate, re-categorization of the variables were performed and described. The modeling was initiated according to the fit of the complete model, containing all candidate variables; the non-significant ones were withdrawn, one by one, until a more parsimonious model was obtained, containing only significant variables ${ }^{20}$. It is important to highlight the exploratory nature of this sort of work, without pretension of causal relation between the explanatory variables and the analyzed outcomes.

This study was approved nationally by the Research Ethics Committee of the National School of Public Health from Fundação Oswaldo Cruz (CEP/ENSP/Fiocruz) as well as locally by the Research Ethics Committee of the Health Science Teaching and Research Foundation (Fepecs) (CAAE: 49359415.9.0000.5240 and Opinion No. 1.787.606). The database was provided by the Department of Chronic Conditions Diseases and Sexually Transmitted Infections of the Health Surveillance Secretariat of the Ministry of Health.

\section{RESULTS}

This study showed that of the 201 participants, more than half identified as transgender women (54.5\%), followed by travestis (30.4\%), and $14 \%$ self-referred to themselves as women, regardless of classifications such as trans or cisgender (Table 1).

Regarding the age group, there is a young sample, with $79.9 \%$ up to 34 years. The mean age was 28.2 years (95\% CI: 25.9-30.5) and the median was 24 (Q1:22, Q3:30). In general, participants started the transition from the male gender assigned at birth to the female gender at an early age. 
Table 1. Sociodemographic profile of the 201 participants of Pesquisa Divas in the Federal District, 2017.

Sociodemographic variables

$\%(95 \% \mathrm{Cl})$

Gender identity $(n=201)$

\begin{tabular}{|c|c|}
\hline Women & $14(5.2-22.7)$ \\
\hline Transgender woman & $54.5(42.2-66.8)$ \\
\hline Travesti & $30.4(19.4-41.4)$ \\
\hline Others & $1.1(0.3-1.9)$ \\
\hline \multicolumn{2}{|l|}{ Transition onset age $(n=201)$} \\
\hline Before 16 years & $29.9(18.6-41.1)$ \\
\hline Between 16 and 18 years & $39.4(27.8-51)$ \\
\hline After 18 years & $30.7(18.1-43.3)$ \\
\hline \multicolumn{2}{|l|}{ Age group $(n=201)$} \\
\hline $18-24$ years & $46.3(34-58.7)$ \\
\hline $25-34$ years & $33.6(21.3-45.8)$ \\
\hline $35-49$ years & $15.3(5.9-24.5)$ \\
\hline $50-64$ years & $4.8(0-10.4)$ \\
\hline \multicolumn{2}{|l|}{ Race/color $(n=201)$} \\
\hline White & $27.5(16-39)$ \\
\hline Black & $17.3(9.7-24.9)$ \\
\hline Brown & $50.4(37.9-62.7)$ \\
\hline Others & $4.8(0.2-9.4)$ \\
\hline \multicolumn{2}{|l|}{ Schooling $(n=201)$} \\
\hline Elementary School & $28.7(19.2-38.1)$ \\
\hline High School & $48(35.5-60.4)$ \\
\hline Higher Education & $21.4(11.6-31.1)$ \\
\hline Graduate degree & $1.9(0-6.6)$ \\
\hline \multicolumn{2}{|l|}{ Occupation $(n=201)$} \\
\hline Formal work (with a formal contract) & $12.6(2.2-22.8)$ \\
\hline Informal work (no formal contract) & $9.3(3-15.5)$ \\
\hline Self-employed & $58.7(46.7-70.8)$ \\
\hline Student & $9(4-14)$ \\
\hline Unemployed & $10.4(4.4-16.3)$ \\
\hline \multicolumn{2}{|c|}{ Have you done sex work in the last 30 days $(n=201)$} \\
\hline Yes & $43.9(31.3-56.5)$ \\
\hline No & $56.1(43.5-68.6)$ \\
\hline \multicolumn{2}{|l|}{ Income $(n=201)$} \\
\hline Up to 2 monthly minimum wages & $52.7(39.3-66.1)$ \\
\hline 2 to 4 monthly minimum wages & $27.7(14.6-40.7)$ \\
\hline 4 or more monthly minimum wages & $19.6(8.3-30.9)$ \\
\hline
\end{tabular}


The majority started the process before reaching the age of $18(68.3 \%)$, the youngest being 7 years old and the oldest being 58 . The mean was 18 years (95\% CI: 16.6-19.4) and the median was 17 (Q1:15, Q3:19).

More than half of the interviewees were self-declared brown $(50.4 \%)$, followed by white $(27.5 \%)$ and black (17.3\%). Schooling was concentrated among those who studied until primary and secondary education (56.7\%). A smaller amount was able to reach higher levels of formal education (about 24\%).

Most of the participants reported working as self-employed (58.7\%), while only $12.6 \%$ declared formal work (with formal contract). The majority responded that they receive up to four minimum wages per month $(80.4 \%)$. There was also a small part of the interviewees who reported that they were studying $(9 \%)$. Almost half reported having done sex work in the last 30 days (43.9\%).

Table 2 presents information related to the use of hormones among participants, including their motivations, the types of hormone used, the respective route of administration and who administers it (if injected). These issues allowed for more than one response from each participant. Access to medication and user satisfaction with hormones are also described in Table 2.

The data reveal that the participants started using hormones with a mean age of 18.7 years (95\% CI: 17.5-19.9). Table 2 also shows that most interviewees (64.5\%) had already taken and continued to take hormones for body feminization.

Regarding the factors associated with the continuous use of hormones, the proposed logistic model (Table 3 ) showed that older individuals are less likely to make continuous use of hormones, as well as people who declare themselves black. People with higher incomes are more likely to make continuous use, unlike those who reported having had sex work in the last 30 days.

Regarding the type of hormone, the most used drug is that which combines estrogen and progesterone in the same formulation (about $87 \%$ of participants declare using it). The injectable and oral methods of administration were the most frequently chosen $(75 \%$ and $\cong 66 \%$, respectively).

Only $35 \%$ of the interviewees reported antiandrogen use. It is worth mentioning that, with regard to the injectable administration, more than half of the interviewees $(55.7 \%)$ reported that the drug had been applied by a pharmacy clerk.

Regarding access, $84 \%$ of the participants reported that they purchased the hormones directly from pharmacies, without medical prescription. More than half of them reported having received advice about their use of the drug, mostly through their peers (other transgender women or travestis), or some health professional. The logistic regression model (Table 4) shows that, compared to the white, young and intermediate age group (25 to 34 years old), with lower income and schooling, used as reference in the model, individuals with higher income and schooling are more likely to seek guidance from health professionals about the use of hormones (the opposite option was for travestis/transgender couples). 
Table 2. Distribution of information related to the use of hormones. Federal District, 2017.

\section{Issues related to hormone use}

Age at which started using hormones (mean)

Use of hormones

Used before and keeps using

Used before but not anymore

Never used

Type of hormone used

\begin{tabular}{l|c}
\hline Estrogen & $13.5(6.2-20.8)$ \\
\hline Progesterone & $6.8(0.1-13.6)$ \\
\hline Estrogen + progesterone & $86.2(78.2-94.1)$ \\
\hline Antiandrogen & $35.7(22.9-48.5)$ \\
\hline Isoflavone & $1.4(0.0 .0-7.3)$ \\
\hline
\end{tabular}

Route of hormone administration

\begin{tabular}{|c|c|}
\hline Injectable & $75.1(64.1-86.2)$ \\
\hline Oral & $65.9(52.9-79)$ \\
\hline Transdermal gel & $5.4(0.0 .0-13.1)$ \\
\hline Patch & $18.9(7.0 .0-30.8)$ \\
\hline Others & $0.1(0.0 .0-0.1)$ \\
\hline \multicolumn{2}{|l|}{ Where hormone is acquired } \\
\hline Pharmacy without prescription & $84(74.1-94)$ \\
\hline Pharmacy with prescription & $7.9(0.0 .0-16.1)$ \\
\hline Friends/co-workers & $8.7(0.0 .0-17.4)$ \\
\hline Bombadeiras & - \\
\hline Other transgender people & $5.3(1.4-9.2)$ \\
\hline SUS & $0.9(0.4-1.3)$ \\
\hline Internet & $1.4(0.0 .0-7.3)$ \\
\hline Received guidance on hormone use care & $55(41.9-68.1)$ \\
\hline \multicolumn{2}{|l|}{ Who provided guidance } \\
\hline General health professional & $39.3(21.6-57)$ \\
\hline Endocrinologist & $17.5(1.2-33.7)$ \\
\hline Other Travestis/Transgenders & $40.8(24.0 .0-57.5)$ \\
\hline Bombadeira & $5.2(0.0 .0-15)$ \\
\hline
\end{tabular}

Bombadeira: Non-healthcare professionals (often travestis or transgender women) who apply industrial silicone in travestis and transgender women. 
Table 3. Final model adjusted for the question "Do you make continuous use of hormones?".

\begin{tabular}{|c|c|c|c|c|}
\hline Variable & Level & OR & $95 \% \mathrm{Cl}$ & P-value \\
\hline \multicolumn{5}{|c|}{ Performed sex work in the last 30 days } \\
\hline & No & 1 & - & - \\
\hline & Yes & 0.84 & $0.716-0.995$ & 0.0447 \\
\hline \multicolumn{5}{|c|}{ Age Group } \\
\hline & $18-34$ & 1 & - & - \\
\hline & 35 or more & 0.81 & $0.668-0.974$ & 0.027 \\
\hline \multicolumn{5}{|c|}{ Race/Color } \\
\hline & White & 1 & - & - \\
\hline & Black & 0.81 & $0.659-0.997$ & 0.049 \\
\hline & Brown & 1.01 & $0.856-1.187$ & 0.924 \\
\hline & Others & 0.93 & $0.654-1.318$ & 0.678 \\
\hline \multicolumn{5}{|l|}{ Income } \\
\hline & $<2 \mathrm{MW}$ & 1 & - & - \\
\hline & 2-4 MW & 1.14 & $0.953-1.352$ & 0.156 \\
\hline & $>4 \mathrm{MW}$ & 1.37 & $1.125-1.659$ & 0.002 \\
\hline
\end{tabular}

$\mathrm{Cl}$ : confidence interval; OR: odds ratio; MW: minimum wages.

Table 4. Final model adjusted for the question "Have you received advice from a health professional about the use of hormones?".

\begin{tabular}{|c|c|c|c|c|}
\hline Variable & Level & OR & $95 \% \mathrm{Cl}$ & P-value \\
\hline \multicolumn{5}{|c|}{ Age group } \\
\hline & $18-24$ & 1 & - & - \\
\hline & $25-34$ & 1.24 & $1.067-1.435$ & 0.005 \\
\hline & 35 or more & 1.08 & $0.902-1.294$ & 0.403 \\
\hline \multicolumn{5}{|c|}{ Race/color } \\
\hline & White & 1 & - & - \\
\hline & Black & 0.74 & $0.613-0.903$ & 0.003 \\
\hline & Brown & 0.82 & $0.704-0.953$ & 0.011 \\
\hline & Others & 0.69 & $0.506-0.931$ & 0.017 \\
\hline \multicolumn{5}{|c|}{ Schooling } \\
\hline & $\begin{array}{l}\text { Up to Primary } \\
\text { School }\end{array}$ & 1 & - & - \\
\hline & High School & 1.30 & $1.114-1.516$ & 0.001 \\
\hline & $\begin{array}{l}\text { Higher Education } \\
\text { or higher }\end{array}$ & 1.24 & $1.032-1.493$ & 0.023 \\
\hline \multicolumn{5}{|l|}{ Income } \\
\hline & $<2 \mathrm{SM}$ & 1 & - & - \\
\hline & 2 or more & 1.16 & $1.017-1.325$ & 0.029 \\
\hline
\end{tabular}

$\mathrm{Cl}$ : confidence interval; OR: odds ratio; MW: minimum wages. 


\section{DISCUSSION}

This study had a young sample beginning their transition from male to female, also at an early age, on average at 18 years of age. People of brown race/color and with high school complete were predominant. The average income of the interviewees was low, with a large majority not exceeding four minimum wages per month, as already observed in other studies. For example, in the research by Grinsztejn et al. ${ }^{21}$, held in Rio de Janeiro and in Baixada Fluminense, the sample of 345 participants was also mainly constituted of those who referred to themselves as travestis and transgender women, only being different in that in Rio de Janeiro, most were self-declared travestis, followed by transgender women. A study conducted in São Paulo by Pinto et al. ${ }^{22}$, with 576 participants, found the same identity pattern as that of the Federal District, with the majority being transgender women, followed by travestis.

With respect to age, these studies also had a young sampling. The median of the present study was 24 years, while in Rio de Janeiro it was 28 . An investigation conducted in Fortaleza $^{23}$ with 304 participants, resulted in half of the sample being less than 24 years old; and in São Paulo a mean of 32 years. It can be seen that most studies, even those of RDS, end up approaching young populations, and as such the profile of more advanced ages remains unknown.

Regarding race/color, as in the Federal District, the majority of respondents from São Paulo and Fortaleza were self-referred brown, white and black, respectively. In Rio de Janeiro, the only difference was that the self-reported black people were ahead of white, but with brown people as the most prevalent. Here, the brown and black categories were over-represented compared to the Continuous National Household Sample Survey (Pnad-C - Pesquisa Nacional por Amostra de Domicílios Contínua) of $2016^{24}$, in which $\cong 46 \%$ and $\cong 8 \%$, respectively, declared themselves as brown and black. White people were underrepresented compared to Pnad-C, which had $\cong 44 \%$ of white people.

The reported schooling is quite similar between all the studies, with the majority of respondents reporting having completed high school, as well as with regard to monthly income, which was from low to average, according to participants' reports. Both data also meet the Pnad-C of $2016^{24}$. International studies carried out using the same methodology present similar socioeconomic patterns ${ }^{25}$.

As for the type of hormone used, the most common one was the combination, in the same formulation, of estrogen and a progestogen, administered through injections or tablets, respectively. Often, access to these hormones is straightforward in pharmacies with no medical prescription, and guidelines on use come from peers. The level of satisfaction of these drugs is high, and unwanted effects lead to discontinuation of use.

The distribution of hormone use is also reported in studies by Grinsztejn et al. ${ }^{21}$ and Pinto et al. ${ }^{22}$. Most interviewees from the Rio de Janeiro and São Paulo surveys report that they were using these drugs. Another study ${ }^{26}$, also cross-sectional, but conducted by snowball methodology with 673 participants and specifically addressing the use of hormones, 
offers greater detail on the practice. Many similarities between the surveys are found, with differences in sample size and method being preserved. While in this study about $65 \%$ of the interviewees report use of hormones, in the study by Maschião et al. ${ }^{26}$ this value was higher than $90 \%$. The mean onset age of hormone use in São Paulo was 17 years, and 18 years in the Federal District. The study conducted in São Paulo did not explore the types of hormones used, however, similarly to this study in Brasilia, it demonstrated that the majority of respondents (more than $80 \%$ in both cases) purchase these drugs without a prescription.

These data corroborate results from the Brazilian Survey on Access, Use and Promotion of the Rational Drug Usage (PNAUM - Pesquisa Nacional de Acesso, Utilização e Promoção do Uso Racional de Medicamentos) ${ }^{27}$, which interviewed 41,433 people between September and February 2014, finding a prevalence of self-medication of 16.1\%. PNAUM also includes stratification per drug class, which shows a prevalence of use of hormonal contraceptive drugs equal to $32.7 \%$, with $28.2 \%$ being oral contraceptives and $4.5 \%$ injectable. Cases of self-medication reach $3.1 \%$ in this pharmacological class. The study also points out that most users reported using single-phase combined oral contraceptives (estrogen and progesterone), representing $73.9 \%$ of all contraceptives identified, similarly to the results described in the present study.

The literature suggests that transgender women and travestis self-medicate due to lack of access to health services and supplies, a barrier imposed by the precarious care of this population, denial of their public existence, stigmatization and discrimination ${ }^{9,10}$. This scenario of cis-heteronormativity and biopolitical control of bodies in health services leads to the exclusion of certain identities due to a hegemonic binary-sexual perspective in the biomedical sciences, according to the logistic model demonstrated in Table $3^{28,29}$.

This is also reflected in the lack of professional guidance on the use of these hormones, as shown in the proposed logistic model (Table 4). The fact that the older age group is not significant may reflect less statistical power or even a generational issue. Individuals of other races/colors were also shown to be less likely to seek guidance from health professionals than white people.

The National Drug Policy provides access to essential medicines contained in the Brazilian Drug List (Rename - Relação Nacional de Medicamentos) ${ }^{30}$. The constants are simply cyproterone acetate, finasteride and some conjugated estrogens, which does not comprise all prescription possibilities. This fact can be attributed to the lack of an Evidence-Based Clinical Protocol and Therapeutic Guidelines (PCDT) to subsidize a change in Rename, following the guidelines for access to the Processo Transexualizador (Transexualizing Process) provided for in the National LGBT Comprehensive Health Policy (PNSILGBT - Politica Nacional de Saúde Integral LGBT) ${ }^{8}$.

The Butlerian concept of intelligibility helps to understand the attempt to escape from a place of abjection to a place of social existence belonging to the feminine world ${ }^{5}$. The search for a fair and youthful beauty pattern is a possible explanatory hypothesis ${ }^{31,32}$.

Transcending the notion of the body as a mere device of self-satisfaction with one's own image, configured in a social self-protection device, an "ever closer to that of a cis woman" appearance can avoid daily social constraints and transphobic violence. Brazil is the country with the highest number of murders of trans people due to transphobic motivations ${ }^{32}$. 
This study has the limitation of having worked with a small sample and whose total universe (number of transgender people in the Federal District, or even Brazil) is unknown ${ }^{17}$. Due to the punctual nature of cross-sectional studies, prevalence/survival bias may also be present. In the case of a population that is marginalized and stigmatized as trans and whose average life expectancy in Brazil is estimated to be 35 years ${ }^{32}$, the fact it covers restricted age groups and certain social strata may lead to the concern of a possible generalization from the sample. In order to minimize this bias, the training research prior to the application of the questionnaires was careful to bring people quite different from each other, namely the seeds that initiated the bringing up of participants into the study.

There is also the influence of selecting RDS itself, whose sampling can still be considered for convenience, and therefore not probabilistic. Most invited people tend to recruit those with whom they resemble in race, ethnicity, education, income, religion, and other variables. This effect is known as homophilia ${ }^{17}$. For this reason, Bastos et al. ${ }^{16}$ point out that the findings of the study cannot be extrapolated either to the country, or even to the city/ study site, thus only being representative of the researched network itself.

\section{CONCLUSION}

Public and private health services need to expand access for transgender people. This translates into an increase in the number of services, decentralization of care to other sections of the healthcare network and more awareness among professionals. The creation of a PCDT by the Ministry of Health based on evidence and the consequent insertion of medicine for hormonalization of trans people in Rename are essential to increase access.

The structure of these services requires cultural competence in the integral reception of trans people, considering the health needs that go beyond the Processo Transexualizador (Transexualizing Process). To implement this reality in the life of trans people, the principle of equity, equally guaranteed in SUS, should guide health actions.

It is of utmost importance that there be continuous thought on the health of transgender people. Care must take into account the value of diversity in the trans collective, without being tied to the institutional requirement prescribind what is considered better in terms of hormonalization, but listening to demands, reproductive desires, and the practice of commercial sex. In order for PNSILGBT to take effect, the integral and integrated view of other sectors of society, in addition to the healthcare field, is essential in understanding trans people as subjects with full citizenship and rights.

\section{REFERENCES}

1. Reis T., editor. Manual de Comunicação LGBTI+. Curitiba: Aliança Nacional LGBTI/ GayLatino; 2018.
2. Louro GL. Gênero, sexualidade e educação: uma perspectiva pós-estruturalista. Petrópolis: Vozes; 2008. 
3. Rodovalho AM. O cis pelo trans. Rev Estud Fem. 2017;25(1):365-373. http://dx.doi.org/ 10.1590/1806-9584.2017v25n1p365

4. Jesus JG. Orientações sobre identidade de gênero: conceitos e termos. Guia técnico sobre pessoas transexuais, travestis e demais transgêneros, para formadores de opinião. Brasília, DF: Autor; 2012.

5. Butler J. Problemas de gênero: feminismo e subversão da identidade. Rio de Janeiro: Civilização Brasileira; 2003.

6. Petry RA. Mulheres transexuais e o Processo Transexualizador: experiências de sujeição, padecimento e prazer na adequação do corpo. Rev Gaúcha Enferm. 2015;36(2):70-5. http: / / dx.doi.org/ 10.1590/1983-1447.2015.02.50158.

7. Bento BA. A reinvenção do corpo: sexualidade e gênero na experiência transexual. Rio de Janeiro: Garamond; 2006.

8. Brasil. Ministério da Saúde. Secretaria de Gestão Estratégica e Participativa. Departamento de Apoio à Gestão Participativa. Política nacional de saúde integral de lésbicas, gays, bissexuais, travestis e transexuais. Brasília, DF; 2013.

9. Rocon PC, Sodré F, Zamboni J, Rodrigues A, Roseiro MCFB. O que esperam pessoas trans do Sistema Único de Saúde? Interface. 2018;22(64):43-53. http: / / dx.doi.org/10.1590/1807-57622016.0712

10. Arán M, Murta D, Lionço T. Transexualidade e saúde pública no Brasil. Ciên Saúde Coletiva. 2009;14(4):1141-1149. http:// dx.doi.org/10.1590/ S1413-81232009000400020

11. Bränstörm R, van der Star A. All inclusive Public Health - what about LGBT populations? Eur J Public Health. 2013;23(3):353-4. https: / / doi.org/10.1093/ eurpub/ckt054

12. Brasil. Ministério da Saúde. Portaria $n^{\circ} 1.707$, de 18 de agosto de 2008 (revogada pela PRT GM/MS $\mathrm{n}^{\mathrm{o}} 2.803$, de 19 de novembro de 2013). Institui, no âmbito do Sistema Único de Saúde (SUS), o Processo Transexualizador, a ser implantado nas 50 unidades federadas, respeitadas as competências das três esferas de gestão. Diário Oficial da União [Internet]. Brasília, DF; 2008 [cited 2018 Nov 18]. Available from: http:/ / bit.ly/2LKVfdR

13. Brasil. Ministério da Saúde. Portaria n ${ }^{\circ} 2.803$, de 19 de novembro de 2013. Redefine e amplia o Processo Transexualizador no Sistema Único de Saúde (SUS). Diário Oficial da União [Internet]. Brasília, DF; 2013 [cited 2018 Nov 18];226:25. Available from: http:// bit.ly/2KYEImy

14. Coleman E, Bockting W, Botzer M, Cohen-Kettenis P, DeCuypere G, Feldman J, et al. Normas de atenção à saúde das pessoas trans e com variabilidade de gênero. Associação Mundial Profissional para a Saúde Transgênero [Internet]; 2012 [cited 2018 Nov 18]. Available from: http://bit.ly/2JoineL

15. Deutsch MB, Bhakri V, Kubicek K. Effects of cross-sex hormone treatment on transgender women and men. Obstetr Gynecol. 2015;125(3):605-10. https: / / doi.org/ 10.1097/ AOG.0000000000000692

16. Bastos FI, Bastos LS, Coutinho C, Toledo L, Mota JC, Velasco-de-Castro CA, et al. HIV, HCV, HBV, and syphilis among transgender women from Brazil: assessing different methods to adjust infection rates of a hard-to-reach, sparse population. Medicine. 2018;97(1S Supl 1):S16-24. https:/ / doi.org/10.1097/ MD.0000000000009447

17. Volz E, Heckathorn DD. Probability based estimation theory for respondent-driven sampling. J. Off. Stat [Internet]. 2008 [cited 2018 Nov 18];24(1):79-97. Available from: http:/ / bit.ly/2RTbfuw

18. R Development Core Team. R: a language and environment for statistical computing. Vienna: The R Foundation for Statistical Computing; 2011.

19. Handcock MS, Fellows IE, Gile KJ. RDS: RespondentDriven Sampling, Version 0.8-1 [software]. 2012 [cited 2018 Nov 18]. Available from: http:/ / bit.ly/2FPhgDS

20. Sperandei $S$. Understanding logistic regression analysis. Biochem Med. 2014;24(1):12-18. https:// doi.org/10.11613/BM.2014.003

21. Grinsztejn B, Jalil EM, Monteiro L, Velasque L, Moreira RI, Garcia AC, et al. Unveiling of HIV dynamics among transgender women: a respondentdriven sampling study in Rio de Janeiro, Brazil. Lancet HIV. 2017;4(4):e169-e176. https:// doi.org/10.1016/ S2352-3018(17)30015-2

22. Pinto TP, Teixeira FB, Barros CRS, Martins RB, Saggese GSR, Barros DD, et al. Silicone líquido industrial para transformar o corpo: prevalência e fatores associados ao seu uso entre travestis e mulheres transexuais em São Paulo, Brasil. Cad. Saúde Pública. 2017;33(7):e00113316. https:/ / doi.org/ 10.1590/0102-311X00113316

23. Martins TA, Kerr LR, Macena RH, Mota RS, Carneiro KL, Gondim RC, et al. Travestis, an unexplored population at risk of HIV in a large metropolis of Northeast Brazil: a respondent-driven sampling survey. Aids Care. 2012;25(5):606-12. https: / / doi. org/10.1080/09540121.2012.726342

24. Brasil. Instituto Brasileiro de Geografia e Estatística. Pesquisa Nacional por Amostra de Domicílios Contínua (Pnad-C) [Internet]. Brasília, DF; 2016 [cited 2018 Nov 18]. Available from://bit.ly/2XqhvLJ.

25. Yi S, Ngin C, Tuot S, Chhoun P, Chhim S, Pal K, et al. HIV prevalence, risky behaviors, and discrimination experiences among transgender women in Cambodia: 
descriptive findings from a national integrated biological and behavioral survey. BMC Int Health Hum Rights. 2017;17(1):14. https: / / doi.org/10.1186/ s12914-017-0122-6.

26. Maschião LF, Rocha ABM, Prado I, Pinto TP, Veras MA. Uso de hormônios sem prescrição e idade de início entre mulheres transexuais e travestis. Anais do $10^{\circ}$ Congresso Brasileiro de Epidemiologia; 10-14 out. 2017; Florianópolis, Brasil. Florianópolis: Abrasco/ UFSC; 2017. p. 12-35.

27. Brasil. Ministério da Saúde. Secretaria de Ciência, Tecnologia e Insumos Estratégicos. Departamento de Assistência Farmacêutica e Insumos Estratégicos. Departamento de Ciência e Tecnologia. Componente populacional: resultados. Série PNAUM - Pesquisa Nacional sobre Acesso, Utilização e Promoção do Uso Racional de Medicamentos no Brasil. Caderno 3. Brasília, DF; 2016

28. Santos DBC. A biopolítica educacional e o governo de corpos transexuais e travestis. Cad Pesqui. 2015;45(157):630-651. http:// dx.doi.org/ $10.1590 / 198053142970$

29. Foucault M. Nascimento da biopolítica. São Paulo: Martins Fontes; 2008.

30. Brasil. Ministério da Saúde. Gabinete do Ministro. Portaria $\mathrm{n}^{\circ} 3.916$, de 30 de outubro de 1998. Aprova a Política Nacional de Medicamentos. Diário Oficial da União [Internet], Brasília, DF; 1998 [cited 2018 Nov 18]. Available from: http://bit.ly/2LCAujR

31. Foucault M. Os anormais. São Paulo: Martins Fontes; 2001.

32. Transgender Europe (TGEU). Projeto de investigação TvT. Observatório de Pessoas Trans Assassinadas (TMM). Atualização TDoR [Internet]. 2016 [cited 2018 Nov 18]. Available from: http:/ / bit.ly/2XmFPhv.

Received: 01/23/2019

Final version presented on: 05/06/2019

Approved: 06/18/2019

Acknowledgments: The authors wish to thank the transgender participants, the DCCI/SVS / MS represented by Adele Benzaken, Gerson Pereira, Cristina Pimenta and Gil Casimiro, for providing the database; Francisco Bastos and Monica Malta and the central team of Fiocruz-RJ and other national members; and the other 11 sites of the Pesquisa Diversidade e Valorização da Saúde (Divas). Sperandei S thanks Fundação de Amparo à Pesquisa do Estado do Rio de Janeiro (Faperj) in partnership with the Coordination for the Improvement of Higher Education Personnel (Capes) for the postdoctorate scholarship.

Authors' contributions: Krüger A, Sperandei S, Bermudez XPCD e Merchán-Hamann E conceived the study and wrote the article. Krüger A e Sperandei S contributed with statistical analyses. 